THE MODERN MIDDLE EAST 
"An outstanding textbook on the modern Middle East. Kamrava's writing is straightforward and lucid."

—Digest of Middle East Studies

"This is an ambitious and stimulating treatment of the modern Middle East. It is both informative and enlightening."

-The Historian

"... an in-depth analysis of a variety of issues that have plagued this part of the world for so many years."

-Mahmood Monshipouri, author of Islamism, Secularism, and Human Rights in the Middle East

"At a time when sensational books on the Middle East fill the market, this is a serious and sober contribution. Kamrava approaches the highly charged emotional issues of the Middle East with sensitivity and objectivity. He should be commended for a very useful and highly needed book."

-As'ad AbuKhalil, author of The Battle for Saudi Arabia: Royalty, Fundamentalism, and Global Power

"Kamrava has written a very well-researched, accessible, and up-to-date book. His themes are well chosen; his analysis is cogent and lucid. It is a welcome addition to the literature on Middle East politics."

-Manochehr Dorraj, author of Middle East at the Crossroads 


\section{The Modern Middle East}

A Political History since the First World War

Third Edition

MEHRAN KAMRAVA

甲ㅜ

UNIVERSITY OF CALIFORNIA PRESS

Berkeley Los Angeles London 
University of California Press, one of the most distinguished university presses in the United States, enriches lives around the world by advancing scholarship in the humanities, social sciences, and natural sciences. Its activities are supported by the UC Press Foundation and by philanthropic contributions from individuals and institutions. For more information, visit www.ucpress.edu.

University of California Press

Berkeley and Los Angeles, California

University of California Press, Ltd.

London, England

(C) 2013 by The Regents of the University of California

Library of Congress Cataloging-in-Publication Data

Kamrava, Mehran, 1964-

The modern Middle East : a political history since the First

World War / Mehran Kamrava.-Third edition.

pages $\mathrm{cm}$

Includes bibliographical references and index.

ISBN 978-0-520-27780-9 (cloth : acid-free paper)

ISBN 978-0-520-27781-6 (paper : acid-free paper)

ISBN 978-0-520-95685-8 (ebook)

1. Middle East-History-2oth century. 2. Middle East—History-

21st century. 3. Middle East-Politics and government-2oth

century. 4. Middle East—Politics and government-2Ist century.

I. Title.

DS62.8. $\mathrm{K}_{3} 66 \quad 2013$

956.04-dc23

2013018594

Manufactured in the United States of America
$\begin{array}{llllllllll}22 & 21 & 20 & 19 & 18 & 17 & 16 & 15 & 14 & 13\end{array}$
$\begin{array}{llllllllll}10 & 9 & 8 & 7 & 6 & 5 & 4 & 3 & 2 & 1\end{array}$

In keeping with a commitment to support environmentally responsible and sustainable printing practices, UC Press has printed this book on Natures Natural, a fiber that contains $30 \%$ post-consumer waste and meets the minimum requirements of ANSI/NISO z39.48-1992 (R 1997) (Permanence of Paper). 
To Melisa,

Dilara, and Kendra 
This page intentionally left blank 